\title{
Improvement of surgical outcomes of complete atrioventricular septal defect with Tetralogy of Fallot
}

\author{
K Morimoto \\ From 23rd World Congress of the World Society of Cardio-Thoracic Surgeons \\ Split, Croatia. 12-15 September 2013
}

\section{Background}

The life prognoses after the definitive surgery for complete atrioventricular septal defect with tetralogy of Fallot (CAVSD/TOF) have improved recently. However, the reoperation rate for left sided atrioventricular valve (LAVV) regurgitation is still high. We reviewed our surgical experiences for CAVSD/TOF.

\section{Methods}

Between 1981 and 2013, 23 patients with CAVSD/TOF (8 males, median age at operation: 3.0 year old; median weight at operation: $12.0 \mathrm{~kg}$ ) underwent the definitive surgery: 14 patients before 1995 and 9 patients after 1996. Down syndrome was associated in 17 (74\%) patients. The unilateral or bilateral systemic to pulmonary (SP) shunt was placed in $17(74 \%)$ patients, and the timing of the initial SP shunt after 1996 was significantly earlier than that before $1995(0.1 \pm 0.1$ vs $4.6 \pm 5.8$ year old, $\mathrm{p}=0.0008)$. The timing of the definitive surgery after 1996 was also significantly earlier $(1.3 \pm 0.6$ vs 5.7 \pm 4.5 year old, $\mathrm{p}=0.0001)$. The two-patch repair was applied more frequently after $1996(\mathrm{p}=0.027)$.

\section{Results}

The follow-up was completed on all patients and the mean follow-up was $11.3 \pm 10.7$ years (range, 0.2-32.1). The actuarial survival and freedom from reoperation rates at 30 years were $65.9 \%$ and $76.8 \%$, respectively. No mortality and no reoperation have been seen in 10 patients since 1995. Cox's proportional hazard model revealed that freedom from death or the reoperation rate significantly improved after 1996 when compared to that before $1995(\mathrm{p}=0.0001)$. All four reoperations were for LAVV regurgitation. Post-operative LAVV

Correspondence: peacetree0714@yahoo.co.jp

Department of Pediatric Cardiovascular Surgery, National Cerebral and Cardiovascular Center, Suita, Japan

(c) 2013 Morimoto; licensee BioMed Central Ltd. This is an Open Access article distributed under the terms of the Creative Commons Attribution License (http://creativecommons.org/licenses/by/2.0), which permits unrestricted use, distribution, and reproduction in any medium, provided the original work is properly cited. function was better after 1996 (grade of LAVV regurgitation one year after the definitive surgery; $1.5 \pm 1.0$ vs $2.8 \pm 1.3, \mathrm{p}=0.04)$.

\section{Conclusion}

The surgical outcomes of CAVSD/TOF improved over time. The application of two-patch repair, early and frequent palliative SP shunt, and the early definitive surgery may contribute to preserve the post-operative LAVV function.

Published: 11 September 2013

doi:10.1186/1749-8090-8-S1-P174

Cite this article as: Morimoto: Improvement of surgical outcomes of complete atrioventricular septal defect with Tetralogy of Fallot. Journal of Cardiothoracic Surgery 2013 8(Suppl 1):P174.
Submit your next manuscript to BioMed Central and take full advantage of:

- Convenient online submission

- Thorough peer review

- No space constraints or color figure charges

- Immediate publication on acceptance

- Inclusion in PubMed, CAS, Scopus and Google Scholar

- Research which is freely available for redistribution

\section{() Biomed Central}

C Biomed Central 